\title{
LATVIJAS MEDICĪNAS VĒSTURNIEKU APVIENĪBAS UN MUZEJA DARBĪBAS PĀRSKATS PAR 1999. GADU UN 2000. GADA SĀKUMU
}

1999. gadā no 15. līdz 17. janvārim Vi|ṇā, Lietuvas Zinātṇu akadēmijas ēkā, notika 19. Baltijas zinātṇu vēstures konference, kurā piedalījās dalībnieki no Lietuvas, Latvijas, Igaunijas, Somijas, Polijas, Ukrainas, Baltkrievijas, Krievijas, ASV, Belgijas, Ungārijas un Rumānijas. Konferences pamattēma: kā zinātne sagaida trešo gadu tūkstoti, vēstures pieredze un perspektīvas globālas informācijas tehnologijas êras ievadījumā, zinātnes un tehnikas vēstures loma izglītībā un intelektuālā aktivitātē.

Medicīnas vēstures sekcija darbojās Kauñā, Lietuvas Farmācijas un medicīnas vēstures muzejā. Tajā no Latvijas referēja profesors A. Vīksna, $A M L$ / RSU rektors prof. J. Vētra un doc. J. Salaks. Konferencē piedalījās Latvijas medicīnas vēsturnieki M. Anže, A. Dirbe, E. Jirgena, R. Lindberga, V.Pundure, S. Savenko, J. Surdeko, R. Vainovska un D. Zole. Konferences noslēgumā notika Baltijas zinātṇu vēstures un filozofijas asociācijas generālā asambleja. Par tās prezidentu rotācijas kārtībā ievēlēja Igaunijas ZA akadēmiḳi Karlu Sīlivasku (viceprezidenti - prof. J. A. Krikštopaitis un prof. J. Stradiṇš).

1999. gada 17. janvārī prof. E. Larsens ievēlēts par Baltijas zinātṇu vēstures un filozofijas asociācijas prezidija Ziemeleiropas valstu koordinatoru medicīnā.

1999. gada aprīlī tika plaši atzīmēta profesora Kristapa Rudzīša (1899-1978) simtā dzimšanas diena. Prof. K. Rudzītim veltītie piemiṇas sarīkojumi notika vairākas dienas - tie aizsākās ar J.Liepiṇa grāmatas "Mazais profesors" atvērŠanas svētkiem un preses konferenci Paula Stradina Medicīnas vēstures muzejā 19. aprīlī un noslēdzās ar konferenci Rīgas Latviešu biedrības namā 27. aprīlī. 1999. gadā Latvijas Medicīnas akadēmija iedibināja divas jaunas pieminas balvas medicīnā: Jēkaba Prīmaṇa balvu un Kristapa Rudziša balvu.

12. martā Jēkaba Prīmaṇa Anatomijas muzejā tika pasniegta Jēkaba Prīmaṇa balva Dr. Kārlim Arājam par darbu antropologijā.

23. aprīīi Paula Stradiṇa Medicīnas vēstures muzejā pasniedza Kristapa Rudzīsa balvu profesoram IImāram Lazovskim par īpašiem nopelniem medicīnas zinātnes attīstībā un medicīnas terminologijas veidošanā. 


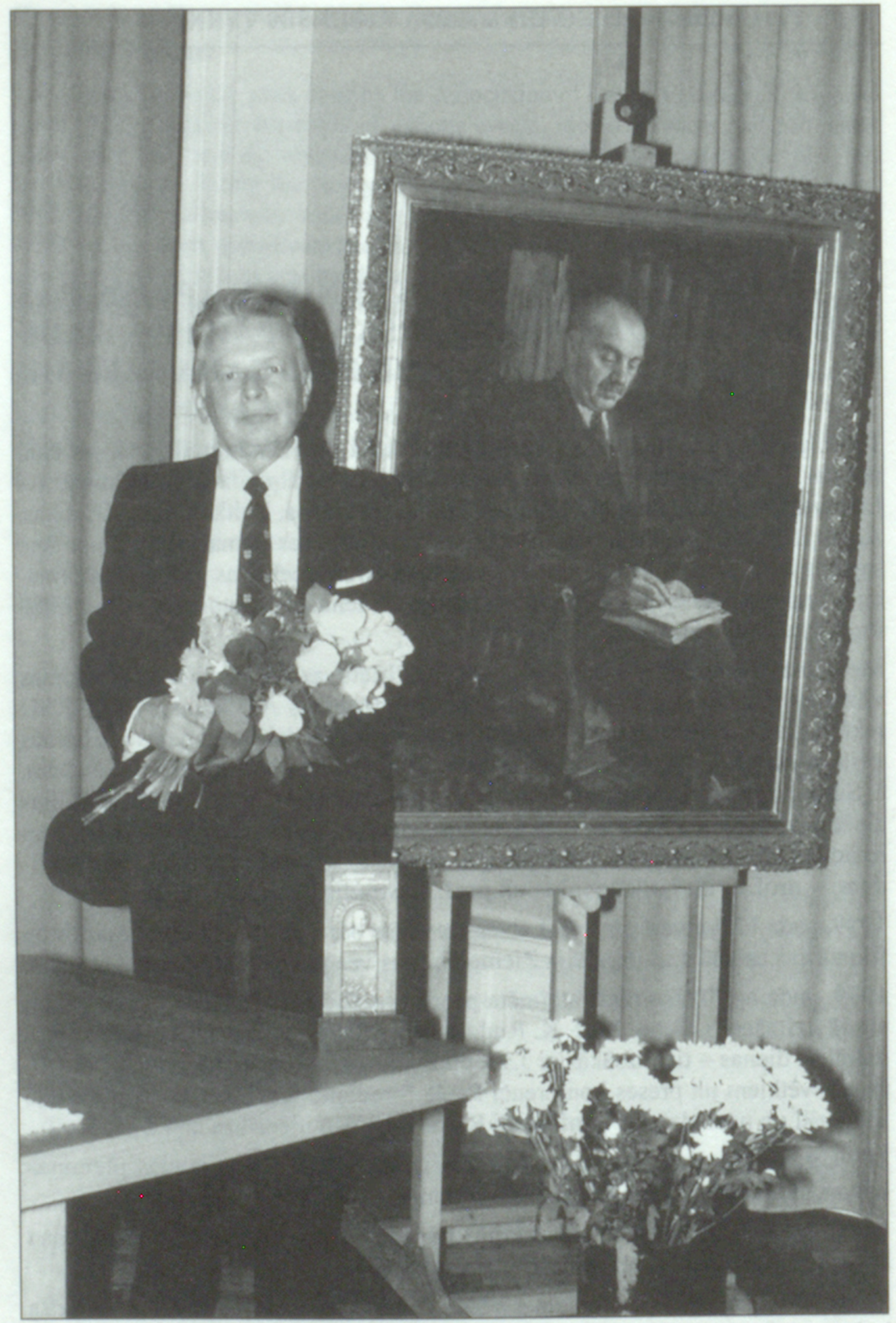

Kristapa Rudzīsa balvas laureāts profesors Ilmārs Lazovskis (foto Jānis Brencis) 
1999. gadā no 27. augusta līdz 2. septembrim Rīgā notika 4. starptautiskais praktiskais seminārs "Medicīnas mulāžu konservācija un restaurācija", ko rīkoja Eiropas Medicīnas zinātṇu vēstures muzeju asociācija un Paula Stradiña Medicīnas vēstures muzejs. Tajā piedalījās dalībnieki no ASV, Lielbritānijas, Holandes, Horvātijas, Krievijas, Baltkrievijas, Latvijas, Lietuvas un Igaunijas. 1999. gada 27. septembrī doc. J. Salaks piedalījās Leipcigā starptautiskajā seminārā "Vācijas un Krievijas sakari medicīnā un farmācijā I8. un 19. gs." (sakarā ar Ivana Pavlova 150. dzimšanas dienu), kur nolasīja referātu "Vācu àrsti un aptiekāri Rīgā 18. un 19. gadsimtā".

1999. gada 8. oktobrī izstāžu zālē Skonto notika Latvijas Ārstu biedrības konference, kurā Latvijas Medicīnas vēsturnieku apvienību pārstāvēja E. Bērziṇa un M. Anže.

1999. gada 22. decembrī docents J. Salaks $A M L /$ RSU Senāta sēdē ievēlēts par asociēto profesoru.

2000. gada 27. janvārī notika Medicīnas vēsturnieku apvienības vēlēšanas, kurās par apvienības priekšsēdi ievēlēja muzeja direktoru docentu K. E. . Aronu, bet 25. februārī par Medicīnas vēsturnieku apvienības goda priekšsēdi tika ievēlēts akadēmiķis J. Stradiņš.

1999. gada 9. oktobrī mirusi ilggadēja Paula Stradiña Medicinas vēstures muzeja speciāliste medicīnas vēsturniece Lilija Ksenofontova (dz. 1933. g.).

\section{HRONIKA}

1999

22. JANVĀRIS. 36. Stradiña lasījumi.

1. K. Ẽ. Arons, J. Salaks. Paula Stradina Medicīnas vēstures muzeja attīstības perspektīvas.

2. A. Valtneris. Prof. R. Krimbergam - 125.

28. JANVĀRIS. Starptautiskās izstādes "Kermeṇa izdaiḷošana (Body Art)" atklāŠana.

12. MARTS. Jēkaba Prīmaņa balvas pasniegšana Dr. Kārlim Arājam Jēkaba Prīmaṇa Anatomijas muzejā.

9.-10. APRIL ıS. Zinātniskā konference "Dr. med. V. Derumam - 100" Jēkaba Prīmaṇa Anatomijas muzejā.

1. R. Grãvere. Senajai tautas dziedniecībai un medicīnai veltīts mūžs.

2. J. Kasmels (Tartu). Prof. J. Prīmaņa studiju gadi Tartu (1911-13).

3. J. Liepiňs. Atmiņas par Dr. med. V. Derumu.

4. I. Buiķis. Paleopatologs V. Derums.

5. R. Jankausks (Vi|̣na). Paleopatologijas attīstības perspektīvas.

6. K. Kallings (Tartu). Apbedījumi Sv. Jāna kapsētā Tartu (13. -14. gs.).

7. R. Lindberga. V. Derums - zinātnieks ar sauli sirdī.

8. Izstāde. 
15. APRĪLIS. Prof. K. Bogojavjenska simtgadei veltīta kopsēde ar Latvijas Anatomu, histologu un embriologu biedrỉbu.

1. A. Dālmane, J. Liepiṇš, J. Êrenpreisa, G. Pakalns. Atmiṇas par prof. K. Bogojavjenski.

2. Izstāde.

19.-23. APRILIS. Prof. K. Rudzī̌a simtajai dzimšanas dienai veltīti sarīkojumi.

1. J. Liepiṇa grāmatas "Mazais profesors" atvēršanas svētki.

2. LU Medicīnas fakultâtes studentu, rezidentu un doktorantu zinātniskā konference LU Mazajā aulā.

3. Latvijas Fizioterapeitu asociācijas izbraukuma sēde Tadaiḳos.

4. Piemiñas akmens atklāšana prof. K. Rudzīša alejā Ķemeros.

5. Kristapa Rudzī̌̌a balvas pasniegšana prof. I. Lazovskim.

6. Grāmatas "Profesors Kristaps Rudzītis" atvēršanas svētki.

22. APRİLIS. Piedalī̌sanās izstādes "No medicīnas vēstures Jelgavas novadā" atklāšanā Ģederta Eliasa Jelgavas vēstures un mākslas muzejā.

1. A. Dirbe. Jelgavas vecmāšu skola 19. gadsimtā.

2. R. Vainovska. J. Hertelis - pirmais latviešu farmācijas magistrs Baltijā

11. MAuss. Rakstu krājuma Acta Medico-Historica Rigensia 4. sējuma (veltīts prof. J. Alkšña dzimtai) atvēršanas svētki.

27. MAIJS. Izstādes "Alus un veselīga sabiedrība" atklāšana. Simpozijs par šo tēmu.

1. Diskusija "Alus un sabiedrïbas veselība".

2. Korporācijas Fraternitas Metropolitana dzīvok|a apmeklējums Kalpaka bulvârī 11.

No jūnija līdz septembrim ik ceturtdienu tematiskas akcijas ("Aldaris un skaistā vasara", "Ielīgošana kopā ar Aldari un SWH", "Līgo vakara virtuve", "Kā ârstēties pēc Jāñiem", “Alus kā hobijs", "Alutinni, vecais brāli...", "Alus Jūsu uzturā", "Alus un skaistumkopక̌ana", "Alus un tā sastāvda|u izmantošana medicīnā", "Alus latviešu folklorā", "No kāda koka taisa prezidenta alus mucu" u.c.).

28. AUGUSTS. 4. starptautiskā praktiskā semināra "Medicīnas mulāžu konservācija un restaurācija" atklāšana.

4. SEPTEMBRIS. Izstādes "Alus un veselīga sabiedrība" noslēgums - "Bibamus et gaudeamus".

14. SEPTEMBRIS. Akad. J. O. Êrenpreisa 70. dzimšanas dienai veltīta kopsēde ar Latvijas Anatomu, histologu un embriologu biedrïbu.

1. A. Dālmane, J. Liepiṇš, G. Eniṇš, J. un J. Êrenpreisi. Atmiṇas par akad. J. Erenpreisu.

2. Izstāde.

21. SEPTEMBRIS. Medicīnas mulāžu izstādes "Kad slimību maskas krît" atklāšana.

23. SEPTEMBRIS. Zinātṇu vẽstures konferences "Latvijas Universitātei - 80" medicīnas un veterinārmedicīnas vēstures sekcijas sēde LU Mazajā aulā. 
1. U. Vikmanis. LU Medicīnas fakultātes dekāni,

2. Z. Brūveris. Profesors L. Kundzin̄š - Latvijas veterināro embriologu skolas dibinătājs.

3. O. Parčinskis, A. Strupulis. Prof. R. Grapmaṇa ieguldījums.

4. G. Preinbergs. Profesors E. Paukuls - LU Veterinārmedicīnas fakultātes dibinātājs.

5. E. Liepiṇš. Prof. M. Rolles zinātniskā un pedagog̀iskā darbība veterinārmedicīnā Latvijā un ārzemēs.

6. M. Baltiņ̌̌. Jauno mācībspēku sagatavošana LU Medicīnas fakultātē 20. un 30 . gados.

7. M.Anže. LU Medicīnas fakultātes absolventi - ārvalstu augstskolu profesori.

8. I.Lazovskis. Internās medicīnas holistiskais virziens LU Medicīnas fakultātē.

9. R. Ligere. Doc. M. Vīgante - diabetolog̀ijas un endokrinologijas pamatlicēja Latvijā.

10. I. Rumba, Ā. Marksa-Ebela. Pediatrija Latvijas Universitātē.

11. M. Mētra. Oftalmolog̉ija Latvijas Universitātē.

12. M. Pilmane. LU Medicīnas fakultātes Anatomijas un histologijas katedra pagātne un tagadne.

13. R. Lindberga. Prof. G. Bakmaña ietekme uz Latvijas un Eiropas zinātnes tālākvirzỉbu.

14. A. Vīksna. Patologa M. Branta darbỉba.

15. V. Miltiņš, I. Poikāne. LU dermatovenerolog̀ijas docētāju starptautiskā sadarbība.

16. I. Ančupāne, A. Miltiņš. Studijas kosmetolog̉ijā.

17. E. Bērziña, A. Dirbe. LU Medicīnas fakultāte Paula Stradina Medicīnas vēstures muzeja krātuvē.

30. SEPTEMBRIS. Paula Stradiņa balvas pasniegšana prof. E. Larsenam (Norvēgejija). Prof. E. Larsena akadēmiskā runa "Jaunākās tendences un uzdevumi medicīnas vēstures mācīšanā".

6. OKTOBRIS. Izstādes "Rīgas Bērnu slimnīcai - 100" atklāšana.

12. NOVEMBRIS. Grāmatas "Medicīnas doktore Lücija Jēruma-Krastina" atvēršanas svētki Jēkaba Prīmaña Anatomijas muzejā, atzīmējot L. Jẽrumas-Krastinas simto dzimšanas dienu.

8. DECEMBRIS. Akadēmiķes V. Rudzītes 70 gadu jubilejai veltīta kopsēde ar LZA Ķīmijas, biolog̉ijas un medicīnas zinātnuu nodalu un Latvijas Kardiolog̀ijas institūtu.

1. K. E. Arons, levadvărdi.

2. V. Rudzīte. 50 darba gados paveiktais.

3. Pārrunas.

16. DECEMBRIS. Izstādes "Ārstu hobiji" (ziloṇu figūras no Dr. A. Lejnieka kolekcijas) atklāšana. 


\section{0}

27. JANVÄRIS. 37. Stradina lasījumi.

1. Paula Stradiña balvas pasniegšana prof. Jānim Klavinam.

2. Grāmatas "Vilhelms un Eduards Deringeri: Rīgas aptiekāru dzimta 19. gadsimtā" atvēršanas svētki.

3. Latvijas Medicīnas vēsturnieku apvienības atskaite par 1999.g. un vēlēšanas.

2.-3. FEBRUĀRIS. Zinātniska konference veltīta Jēkaba Prīmana Anatomijas muzeja un Anatomijas un antropologijas institūta 80. gadskārtai Jēkaba Prīmaṇa Anatomijas muzejā.

24. FEBRUĀRIS. Izstādes "Dvēse/u spoguli" atklāšana.

25. FEBRUĀRIS. Latvijas Zinātṇu vēstures asociācijas gada sanāksme.

1. Akad. J. Stradinnš. Asociācijas pēdējo gadu darbs un turpmākie uzdevumi.

2. I. Grosvalds. Asociācijas sastāvs.

2. MARTS. Prof. H. Šneidera 90 gadu jubilejai veltīta sēde.

1. I. Troickis. Prof. H. Šneidera dzīve un darbs.

2. Izstāde.

22. MARTS. Doc. A. Andrejevas grầmatas "Starp mums, pusmüža sievietēm" atvẽrŠanas svētki.

17. APRILIS. Muzeju Valsts pârvaldes organizētã muzeja akreditācija.

1. Prof. J. Salaks. Muzeja aktualitātes, galvenās problēmas un ieceres šodien un nākotnē.

2. Akad. J. Stradin̄š. Muzeja izveide un attīstība.

5. MAIJS. Nikolaja Rēriha ielas svētki

(kopā ar Latvijas Mākslinieku savienību, UNESCO Latvijas nodalu un LR Kultūras ministriju).

18. MAIJS. Starptautiskās muzeju dienas atzīmēšana.

Roberta Auziña fotogrāfiju izstādes "Zìmoga vietā - 2" atklâšana.

24. MAUSS. Izstādes "Es piedzimu, tu jau biji..." (135 gadi kopā ar Aldari) atklāšana.

24. MAIJS. Latvijas Muzeju asociācijas rịkotie muzeju darbinieku svētki Daugavpilī.

\section{SVARĪGĀKĀS PUBLIKĀCIJAS 1999. GADĀ}

1. Acta Medico-Historica Rigensia: Volumen IV (XXIII). - Rīga, 1999. - 480lpp.

2. Medicīnas doktore Lūcija Jēruma-Krastiṇa / Sast. R. Lindberga, J. Vẽtra. Rīga, 1999. - 74 lpp.

3. Profesors Kristaps Rudzītis (1899-1978): Simtajai dzimšanas veltīts apceru un atmiṇu krājums / Sast. M. Baltinš̌. - Rīga, 1999. - 353 lpp.

4. Vilhelms un Eduards Deringeri: Rīgas aptiekāru dzimta 19. gadsimtā / Sast. S. Pijola. - Rīga, 1999. - 184 lpp. (latviešu un vācu valodā). 


\section{A Review of the Activities of the Association of Latvia's Medical Historians and the Work of the Museum of the Years 1999 and the Beginning of 2000 (Summary) \\ By Maija Anže}

In 1999 from January $15-17$ the $19^{\text {th }}$ Baltic conference on the history of science took place in Vilnius, Lithuania. Members from Latvia, Lithuania, Estonia, Finland, Poland, the Ukraine, Belarus, Russia, USA, Belgium, Hungary and Romania took part in it. In 1999 from August 27 to September 2 the $4^{\text {th }}$ international practical workshop "Restoration and conservation of anatomical and pathological models in wax and other media" took place in Riga, which was organised by the Association of museum of history of medicine in Europe, and the Paul Stradin Museum of the History of Medicine, where representatives of nine states took part - USA, the United Kingdom of Great Britain and Northern Ireland, Netherlands, Croatia, Russia, Belarus, Latvia, Lithuania and Estonia.

In 1999 the Latvian Medical Academy founded 2 new memorial prizes in medicine - the Jēkabs Prīmanis award (for research in anatomy and anthropology) and that of Kristaps Rudzitis (for internal medicine).

In 1999 the museum issued a collection of articles Acta Medico-Historica Rigensia the $4^{\text {th }}$ volume, which was dedicated to the memory of Professor Jekkabs Alksnis (1870-1957) and his family; a book about the family history of Riga chemist Deringer in the $19^{\text {th }}$ century (in Latvian and German) was also published as well as monographies on Prof. Kristaps Rudzitis and Dr. Lūcija Jēruma-Krastina (to celebrate their anniversaries).

In 1999 and 2000, in January the memorial readings dedicated to Paul Stradin birthday also took place. In 1999 several exhibitions were organised as well as several parties dedicated to anniversaries of Latvia's doctors and other activities.

Maija Anže, Mag. hist.

Paula Stradiña Medicinas vēstures muzejs

Antonijas iela 1, LV 1360, Rīga, Latvia

E-mail: museum3@mailbox.riga.lv 


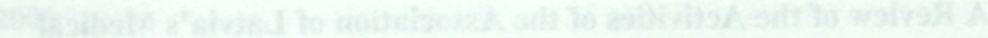

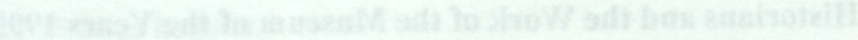

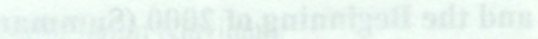

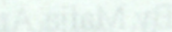

$$
\text { - }
$$

a tararasan 